\title{
Soft Cost Elements in Green Projects: Malaysian building industry
}

\author{
Nurul Zahirah Mokhtar Azizi, Nazirah Zainul Abidin, Azlan Raofuddin
}

School of Housing, Building \& Planning, University Science Malaysia, 11800 USM Penang, Malaysia

zahirahazizi@gmail.com

\begin{abstract}
The most commonly cited green building barrier is the high development costs of construction. Many developers share the common perception that green building construction incurs expensive additional costs. A preliminary study was conducted with four industry experts via semi-structured interviews to investigate the soft cost elements (SCEs) in the project. Eighteen SCEs were identified and categorized into three groups namely Professionals, Procedures, and Legal Requirements. Three of the SCEs were found to be unique to green building and contributed a financial concern. The study rendered that these SCEs may influence a developer's decision to invest in green building development.
\end{abstract}

Keywords: Soft cost elements; green building; developer decision; development cost

eISSN 2398-4295 @ 2018 . The Authors. Published for AMER ABRA cE-Bs by e-International Publishing House, Ltd., UK. This is an open-access article under the CC BY-NC-ND license (http://creativecommons.org/licenses/bync-nd/4.0/). Peer-review under responsibility of AMER (Association of Malaysian Environment-Behaviour Researchers), ABRA (Association of Behavioural Researchers on Asians) and cE-Bs (Centre for EnvironmentBehaviour Studies), Faculty of Architecture, Planning \& Surveying, Universiti Teknologi MARA, Malaysia.

DOI: http://dx.doi.org/10.21834/ajbes.v3i12.130 


\subsection{Introduction}

The benefits of green building as an environmentally responsible concept of modern architecture are numerous and far reaching. The Malaysian Government has shown support through many efforts to bring green buildings to the drawing tables of all professionals involved in the built environment. Nevertheless, green building has received a paradox of opinions from academicians and industry players over many years since it was introduced.

Past research have indicated that green buildings are an attractive investment as they are able to reap higher investment returns and provide benefits including higher occupancy rate and market value, lower risks, higher cost savings from improved energy and water efficiency, and social and environmental benefits such as improved health and work productivity(Isa et al., 2013). However, other studies have refuted this finding and have cited the issue of cost as the biggest barrier preventing the incorporation of sustainable features in building developments (Bond \&Perrett, 2012; Zhang et al., 2011; Sood\& Peng, 2011; ZainulAbidin, 2010; Shari, et al., 2009). This has caused resistance among developers, creating significant social and psychological barriers in green building development (Bandy, et al., 2007; Shafii et al., 2006; Hoffman and Henn, 2008).

Despite various efforts of the Government to drive forward sustainability, green building development in Malaysia remains slow (ZainulAbidin, 2010; Esa et al., 2011). Similar to other countries, cost is also viewed as the main hurdle in attracting wider desirability for green buildings in Malaysia. Cost for construction projects can be divided into three categories i.e. land, hard and soft cost. Land cost will not vary regardless it is a conventional or green project. However, hard and soft costs are believed to be influenced by the choice to be green. Hard cost has been given much attention by scholars, but soft cost has also remained elusive in its contribution to green building cost increment. As such, this paper discusses the nontechnical aspects of project cost and their influence on the overall development from the developers' perspective.

\subsection{Literature Review}

Project cost can be divided into land cost, hard costs and soft costs (Emerging Professional's Companion, 2013; ZahirahM.A. \& ZainulAbidin, 2012; Kubba, 2012; Zhang et al., 2011; Yudelson, 2009). Land costs or site costs cover those expenses for land acquisition and development of the project, which usually includes costs such as land purchase, title transfer, site clearance and others. The Emerging Professional's Companion (2013) defined hard costs as direct physical construction costs and soft costs refer to other various costs incurred to move the project forward. The Transportation Research Board (2010) referred soft costs as the expenses incurred on professional services for completing the project under the Soft Cost Categories (SCCs).

There have been many studies that discuss the additional cost required to include sustainability features in a building (Kubba, 2012; Zhang at al., 2011; T.I.Lam \& Chan, 2011; Tatari \& Kucukvar, 2011). However, Yudelson (2009) reported that the bulk of additional cost in green building does not come from the hard cost, but instead come from soft cost. Most of these costs are incurred in administration processes involved in the project development. A 
study by ZahirahM.A.\& ZainulAbidin (2012) investigating the cost distribution in green buildings had distinguished hard cost and soft cost into ten elements. The hard cost elements cover expenses related to architecture works, mechanical and electrical works, civil and structural works and other physical construction works. The soft cost elements (SCEs) included insurance, developer's experience, design cost, certification, commissioning, and energy modelling. The SCEs were later revised with regards to their role in developers' decision to invest in green building. The revised SCEs included consultants, green building consultant, certification, commissioning, market, and tax (ZahirahM.A. \& ZainulAbidin, 2013). This framework was adopted as the base reference in a preliminary study via interviews with industry experts for validation and identification of new SCEs that were not previously included. Refer figure 1.

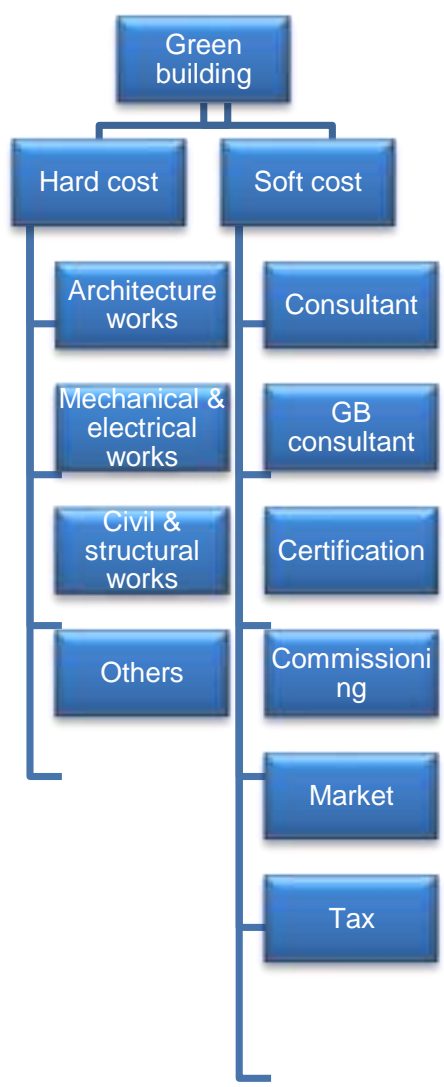

Figure 1: Breakdown of green building cost elements

(Source: ZahirahM.A., N., \& ZainulAbidin, N. (2013). Soft Cost Elements That Affect Developers' Decision to Build Green. International Journal of Civil, Architectural Science and Engineering Vol:7 No:10, 76-80.) 
ZahirahM.A \& ZainulAbidin (2013) explained that few consultants have the ability or expert knowledge to participate in green building projects as this remains a niche area. Hence, the design phase for green building usually demands additional exercises and services from the consultant team, pushing the consultant fee to higher rates (Yudelson, 2009; Means, 2010; Lee, 2010). The Green Building Consultant represented a separate SCE as this is additional to the regular consultant team and contributed additional cost(EE Solutions, 2012). Green buildings need to undergo a rigorous assessment using a green building rating tool in order to be certified green and a certification fee applies. This fee is charged differently depending on the type of project, scale of the project, and rating tool (USGBC, 2013; BCA Green Mark, 2012). Green buildings also have to perform a complex commissioning process to ensure that the green technology features function according to the expected performance (Yudelson, 2009; D'Antonio, 2007). Another SCE is the market factor which influences the asking price for green building depending on the demand and supply ratio(Emerging Professional's Companion, 2013). Lastly, support provided by the Government such as a tax exemption for green building owners should encourage the growth of sustainable development (Emerging Professional's Companion, 2013).

\subsection{Methodology}

A preliminary study using a qualitative approach was conducted with experts from the building industry to understand the local context of cost elements in green building implementation. The qualitative method is suitable for understanding a particular context, and identifying unanticipated phenomena where new theories may be created (Maxwell, 2005).This method enables rich and complex data to be extracted including tacit knowledge, perception and human experience that cannot be measured qualitatively (Easterby-Smith et al., 2002).The snowball sampling technique was used to gather expert information from particular individuals with the most knowledge in the subject area. Snowball sampling is used to locate information-rich sources in a specific population.It is a non-random sampling technique where respondents are asked to nominate other respondents who can offer more information relevant to the study until the point of saturation when no new findings can be found (Morgan, 2004).

In this study, two architects, a quantity surveyor, a developer, and a town planner were identified as the respondents based on industry experience of more than 18 years in building construction. The objective of the interviews is to identify and verify the SCEs sourced from literature in the Malaysian building industry. Each interview lasted an average of 30 to 55 minutes, and was recorded using a voice recording application. The project cost model that was originally adopted from ZahirahM.A \& ZainulAbidin (2013) was then modified according to the interview findings to suit the local context. After the fourth interview, responses from the interviews became stable and deemed to have reached the point of saturation (Creswell, 2012; Glaser \& Strauss, 1967). As the cost model evolved with new inputs, a better understanding of the SCEs in both conventional and green buildings was gained (Bogdan \& Biklen, 2006). 


\subsection{Results and Discussion}

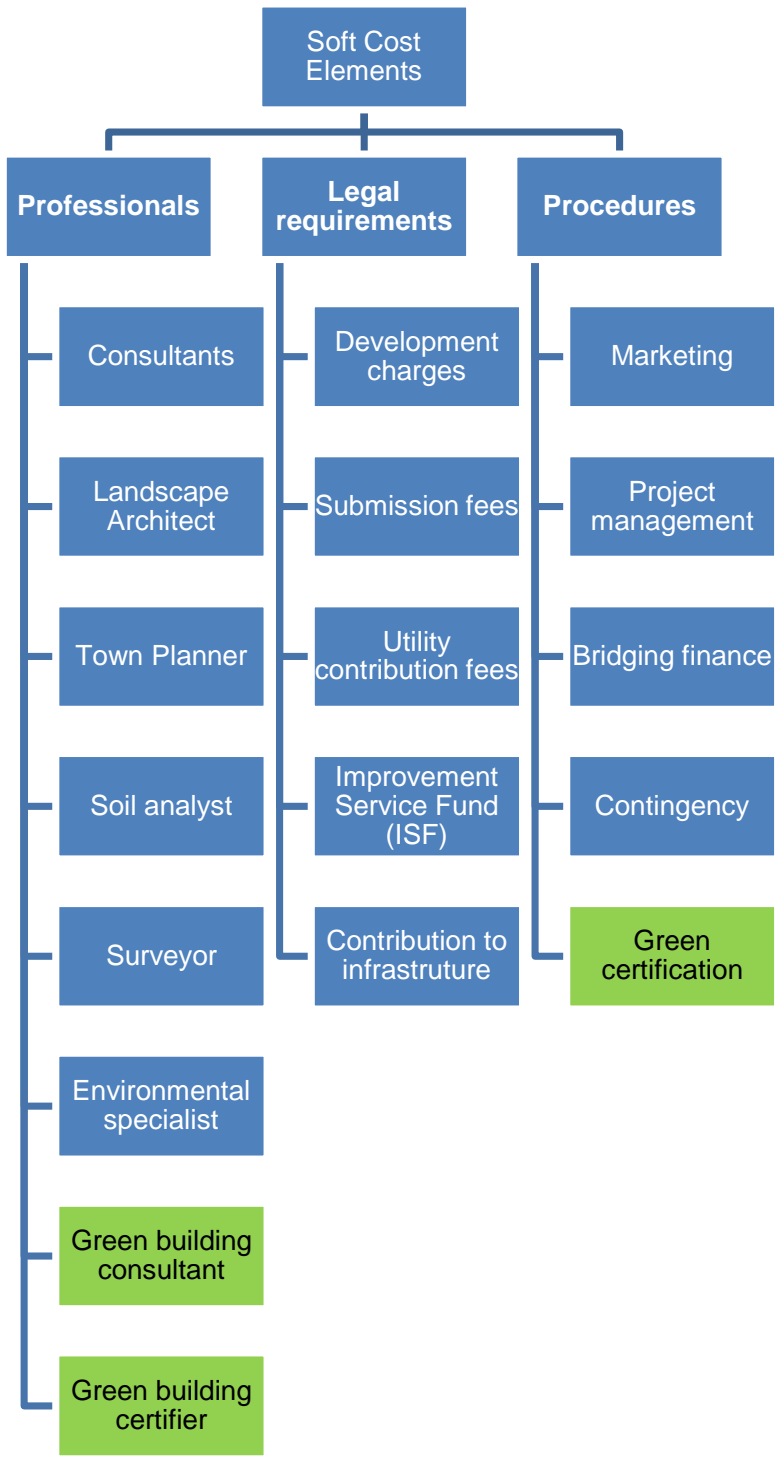

Figure 2: Revised breakdown of green building cost elements based on interview findings (Source: Author, 2014) 


\section{Soft Cost Elements (SCE) Identification}

A new model of soft cost elements was developed based on findings from the interview. See figure 2.Using qualitative analysis of the experts' responses, the study identified eighteen (18) SCEs which are categorized into three different groups i.e. Professionals, Procedures, and Legal Requirements. These groupings comprehensively cover all soft costs elements applicable for both conventional building and green building. Three of the SCEs were found to be unique to green building and may have significant financial impact to the project.

\section{A. Professionals}

The first category is Professionals that enlist SCEs related to necessary experts to engage for the project. There are eight SCEs in this category namely, Consultants, Landscape Architects, Town Planners, Soil Analyst, Surveyor, Environmental Specialist, Green Building Consultant, and Green Building Certifier.

\section{A1 Consultants}

Consultants consist of the regular professional team i.e. Architect, M\&E Engineer, C\&S Engineer, and Quantity Surveyors, who follow through the entire building project from start to finish and are paid successively. The total payment for this team of consultants is usually 6 to 8 percent of the overall project cost depending on the scale of the project.

\section{A2 Landscape Architect}

The Landscape Architect on the other hand, is given a one-off payment of 10 percent out of landscape costs. In some cases however, the payment for landscape architect is included under the payment for Architect. According to industry experts, some Local Authorities require landscape drawings as part of the submission for building approval.

\section{A3 Town Planner}

The Town Planner is paid according to the Board of Town Planners, Malaysia (Lembaga Perancang Bandar Malaysia, 2005)scale of fees which sets a basic fee of RM35,000 plus RM500 per acre of land for planning permission of layout plan approval. This amount is paid successively during the submission to local authority stage until the release of the Development Order.

\section{A4 Soil Analyst}

Soil testing is necessary to assess the suitability of the soil for construction activities, and assist in making informed decisions for the project such as the type of foundation to adopt. This is usually done during the initial phase of the project, before design stage. The fee for soil testing is paid by the developer on a one-off basis to the soil analyst company employed based on the number of points taken for soil testing. 


\section{A5 Surveyor}

The land surveyor is employed to establish the contour and boundaries of the site by producing survey drawings before the start of the project. The fee for land survey is paid oneoff upon completion of the work, and is calculated following the scale of fees for title surveyors (13 schedule) (Land Surveyors Board Malaysia, 2011) under the Licensed Land Surveyor Act 1958.

\section{A6 Environmental Specialist}

Another SCE is the Environmental Impact Assessment (EIA) which is required under section 34A of the Environmental Quality Act 1974 (Amendment 2006) (Environmental Quality Act 1974, 2006). The EIA aims to assess the overall impact on the environment of development projects proposed by the public and private sectors paid to the EIA consultant for developments of more than 50 hectares or sites located within close proximity to natural surroundings such as ocean, river, forest, or hills.

\section{A7 Green Building Consultant}

For green building projects in Malaysia that follow the Green Building Index (GBI) Certification, a Green Building Consultant is required to provide services to enable building projects to achieve GBI accreditation. The Green Building Consultant is a team of licensed professionals who can provide advice on green building design, systems and facilitate certification process. However, payment for the Green Building Consultant is paid separately following the scale of fees set by $\mathrm{GBI}$, which ranges between 0.15 to $0.40 \%$ of the project cost.

\section{A8 Green Building Certifier}

Additionally, a GBI Certifier is engaged to perform a detailed assessment and accreditation of building projects submitted to the GBI Accreditation Panel for GBI Certification. The cost of the GBI Certifier is included in the GBI Application fee. According to the expert panel, this cost is significantly expensive as it is relative to the project size and green certification level aimed for.

\section{B. Legal Requirements}

The second category is Legal Requirements which enlist SCEs payable to Government entities. There are five SCEs in this category namely, development charges, submission fees to the local authority, utility contribution fees, improvement service fund (ISF), and contribution to infrastructure.

\section{B1 Development charges}

Development charges are charged by the local authority of the development area for the land that is to be developed. It varies from project to project depending on the local authority in charge. For example, MajisBandaraya Shah Alam sets the payment at 30 percent of the difference in land value before and after conversion of land use. This payment must be made to the local authority before the Development Order is obtained. 


\section{B2 Submission fees}

Other than that, developers have to pay submission fees to the local authority in order to obtain a development approval. In Kuala Lumpur, DewanBandaraya Kuala Lumpur (DBKL) has set their processing fee at a fixed rate of RM40 per 1000sq for the first 10,000sq, RM20 per 1000 sq for the first 5000 sq, and RM10 for each 1000 sq balance thereof (One Stop Centre $\mathrm{DBKL})$.

\section{B3 Utility contribution fees}

Utility contribution fees usually include payments for sewerage system, water, electric, and telecommunication service supply and are paid to Indah Water Konsortium (IWK), SYABAS, and TNB Malaysia as well as the relevant telecommunication service provider. Under the Street, Drainage and Building Act 1974 Act 133, Part IV Miscellaneous, Section132, developers must pay a contribution fee to the local authority for the beautification, construction or laying of any street, sewer, drain, culvert, gutter or water-course (Street, Drainage and Building Act 1974 Act 133, 1997).

\section{B4 Improvement Service Fund (ISF)}

ISF is revenue collected by the Government under the Street, Drainage and Building Act 1974 (Act 133), Part VI: Section 132. The ISF is administered by the local authority of the development area. For example in Petaling Jaya, the City Council imposes a payment of RM500 for every apartment unit above RM100,000. Monies collected in the ISF are used for improvement of basic amenities like roads and such and overcome problems impacted by the new development in the area.

\section{B5 Contribution to infrastructure}

Another SCE mentioned by the expert panel is the contribution to infrastructure fee. This is an amount set by the local authority if the development area has future planning to install any infrastructures that would benefit the building development. However, the calculation of this fee is unclear and only occurs in certain cases.

\section{Procedures}

The third category is Procedures which enlists those other SCEs in development cost needed to move the project forward. There are five SCEs identified here including marketing, project management, interim finance, contingency and green certification fee.

\section{C1 Marketing}

Marketing cost is the amount allocated in the project development budget to facilitate activities related to sales and promotion of the end product. This is usually three percent of the Gross Development Value (GDV).

\section{C2 Project Team Management}

The project team management cost is dedicated for the staff team managing the project to finance operation and administration costs, including salary of the staffs. This is usually 
capped at 1.75 percent of the building works cost. However, this remains a grey area considering that the same staffs usually administer other projects at the same time and are paid on a regular basis regardless of the projects they handle.

\section{C3 Interim finance}

Interim finance is a short term loan, otherwise called as construction loan provided by banks to pay production costs throughout the construction phase. This will cover expenses to kick start the project and fund construction operations before any revenue can be collected. Findings, show that this amount is usually 50 percent of building works cost, paid over the span of construction phase with an interest depending on the amount of time it takes to complete the project.

\section{C4 Contingency}

Contingency cost is a monetary amount reserved for unforeseeable and uncertain eventualities associated with the normal execution of the project. This is generally five percent of building works cost, but varies according to the degree of uncertainty and risk known at the time of estimation.

\section{C5 Green Certification}

Lastly is the Green Certification Registration fee, which only applies to buildings seeking green accreditation. According to the Green Building Index, the GBI registration fees vary depending on the size of the project. Registration fees start at RM5000 for single residences below $2000 \mathrm{~m} 2$ floor area to RM45,000 for extra-large projects below $100,000 \mathrm{~m} 2$ floor area, and even more for mega projects of more than $100,000 \mathrm{~m} 2$ floor area. Although the cost of obtaining certification may be relatively small compared to the overall project cost, property investors perceive this as one of the main barriers to invest in green development (Bond \& Perrett, 2012). Industry practitioners felt that this cost is expensive and a financial inconvenience to developers considering the additional costs that they have had to factor in to meet green building standards.

\subsection{Conclusions}

A total of eighteen (18) SCEs were derived from interviews with four industry experts and references made to relevant documents and secondary sources. These SCEs are grouped under three categories i.e. Professionals, Legal requirements, and Procedures. Three out of the eighteen SCEs, namely green building consultant, green building certifier, and green building registration are additional elements applied in green buildings. Research findings from the interview analysis indicated that green building construction is complex, and consequently incur additional costs in a number of areas to fulfil the green certification requirements. All respondents agreed that there are too many SCEs incurred at the early project development phase for both conventional and green buildings. Most SCEs are incurred on top of the physical construction costs of a building project and varies directly with the size and complexity of the project. Since green buildings are naturally more complex due 
to the specific standards required meeting, the SCEs in green buildings are also more, adding to the total project cost. The industry experts expressed an unfavourable perception towards green buildings and poor interest to undertake green projects due to financial concerns. The study recommends further exploration into the SCEs to investigate how they affect the choice to build green.

\section{Acknowledgement}

This research is funded by the Ministry of Higher Education (MOHE), Malaysia under the MyBrain15 scholarship

\section{References}

Bandy, R., Danckaert, C., Fetscher, G., Holmes, B., Gale, M., Mursky, M., et al. (2007). LEED in Upstate New York: An Exploration of Barriers, Resources and Strategies. New York: US Green Building Council (USGBC).

BCA Green Mark. (2012, December 12). BCA Green Mark Assessment Fees for Green Building Projects in Singapore. Retrieved March 3, 2013, from Building and Construction Authority: http://www.bca.gov.sg/greenmark/others/GMfees_new.pdf

Bogdan, R.C. \& Biklen, S. K. (2006). Qualitative research for education: An introductory to theory and methods. (5th ed.). Needham Heights, MA: Allyn and Bacon.

Bond, S., \& Perrett, G. (2012). The Key Drivers and Barriers to Sustainable Development of Commercial Property in New Zealand. Journal of Sustainable Real Estate, Vol. 4, No. 1 , 48-77.

Choi, C. (2009). Removing Market Barriers to Green Development: Principles and Action Projects to Promote Widespread Adoption of Green Development Practices. Journal of Sustainable Real Estate, Volume 1, Number 1 , 107-138.

Creswell, J. W. (2012). Qualitative inquiry and research design: Choosing among five approaches. Sage.

D'Antonio, P. C. (2007). Costs and Benefits of Commissioning LEED-NC ${ }^{\mathrm{TM}}$ Buildings. National Conference on Building Commissioning (pp. 1-11). Cambridge: Efficiency Engineering Soultions.

Davis Langdon. (2007). Cost of green revisited: Reexamining the feasibility and cost impact of sustainable design in the light of increased market adoption. Davis Langdon.

EE Solutions. (2012). The Cost of LEED Capital cost is a bit higher when you go Green. Retrieved March 2013, 5, from Energy Efficiency Incorporated: http://www.ee-solutions.com/solutions/Solutions/Cost\%20of\%20LEED.aspx

Emerging Professional's Companion. (2013). 2C - Construction Costs. AIA and NCARB.

Esa, M. R., Marhani, M. A., Yaman, R., Hassan, A. A., Rashid, N. H., \& Adnan, H. (2011). Obstacles in Implementing Green Building Projects in Malaysia. Australian Journal of Basic and Applied Sciences, 5(12) , 1086-1812.

Hoffman, A. J., \& Henn, R. (2008). Overcoming the Social and Psychological Barriers to Green Building. Organization \& Environment, Volume 21, Number 4 , 390-419. 
Isa, M., Rahman, M. M., Sipan, I., \& Hwa, T. K. (2013). Factors Affecting Green Office Building Investment in Malaysia. Procedia - Social and Behavioral Sciences, Volume 105, 3, 138-148.

Kubba, S. (2012). Handbook of Green Building Design and Construction: Leeds, Breeam, and Green Globes. Herndon, Virginia: Butterworth-Heinemann.

Land Surveyors Board Malaysia. (2011). Scale of Fees for Title Surveyors (13 Schedule). Retrieved March 17, 2014 from Land Surveyors Board Malaysia: http://www.ljt.org.my/?q=scale-fees-title-surveyors-13-schedule

Lee, M. (2010). Incentives and Tax Exemption for Green Technology. Green Solutions Property Conference. Kuala Lumpur: PricewaterhouseCoopers.

Lembaga Perancang Bandar Malaysia. (2005). Scale of Professional Fees and General Conditions of Engagement. Lembaga Perancang Bandar Malaysia.

Maxwell, J. A. (2005). Qualitative Research Design: An Interactive Approach . Thousand Oaks, CA: SAGE Publications.

Means, R. (2010). Green Building: Project Planning and Cost Estimating, Volume 24 of RSMeans Series. John Wiley \& Sons.

Morgan, D. L. (2004). Snowball Sampling. In L. M. Given, The SAGE Encyclopedia of Qualitative Research Methods, pp 816-817 (pp. 816-817). SAGE Publications.

Shafii, F., Ali, Z. A., \& Othman, M. Z. ( 2006). Achieving Sustainable Construction in the Developing Countries of Southeast Asia. Proceedings of the 6th Asia-Pacific Structural Engineering and Construction Conference (APSEC 2006) (pp. C29-C44). Kuala Lumpur, Malaysia: Universiti Teknologi Malaysia.

Shari, Z., Jaafar, M. F., Salleh, E., \& Haw, L. C. (2009). The potential of sustainable building rating system in the Malaysian building industry. Wseas Transactions on Environment and Development 5, no. 3, 260-272.

Sood, S. M., \& Peng, K. C. (2011). Sustainable Developmentin the Buildiing Sector: A Green Building Framework in Malaysa. WASET (pp. 08-02). Malaysia: University Tenaga Nasional .

Street, Drainage and Building Act 1974 Act 133. (1997). 132. Improvement Service Fund. Retrieved December 22, 2013, from http://www.cljlaw.com/others/legislationSectiondisplayformat.asp?MY_FS_ACT_1974_133;132.;;

T.I.Lam, P., \& Chan, E. H. (2011). A sustainable framework of "green" specification for construction in Hong Kong. Journal of Facilities Management, Vol. 9, No. 1, 16-33.

Tatari, O., \& Kucukvar, M. (2011). Cost premium prediction of certified green buildings: A neural network approach. Building and Environment $46,1081-1086$.

Transportation Research Board . (2010). TCRP Report 138: Estimating soft costs for major public transportation fized guideway projects. Washington DC: National Academy of Sciences.

USGBC. (2013). Frequently Asked Questions. Retrieved March 3, 2013, from US Green Building Council: http://www.usgbc.org/ShowFile.aspx?DocumentID=3330

Yudelson, J. (2009). Sustainable Retail Development: New Success Strategies. New York: Springer.

Zahira hM.A., N., \& Zainul Abidin, N. (2012). Main Elements of Soft Cost in Green Buildings. World Academy of Science, Engineering and Technology (72) , 992-997. 
Mokhtar Azizi, N.Z., et.al. / Asian Journal of Behavioural Studies (AjBeS), 3(12) Jul / Aug 2018 (p.135-146)

Zahirah M.A., N., \& ZainulA bidin, N. (2013). Soft Cost Elements That Affect Developers' Decision to Build Green. International Journal of Civil, Architectural Science and Engineering Vol:7 No:10, 76-80.

ZainulAbidin, N. (2010). Investigating the awareness and application of sustainable construction concept by Malaysian developers. Habitat International 34 , 421-426.

Zhang, X., Platten, A., \& Shen, L. (2011). Green property development practice in China: Costs and barriers. Building and Environment $46,2153-2160$ 